\section{How expertise could add up to help for developing countries}

[NICE] Developing countries need a capability in cutting edge scientific research including mathematics - to handle difficult social, economic and political choices, according to Claude Lobry, director of the International Centre for Pure and Applied Mathematics (CIMPA) in Nice, France.

"The problems of the poor countries health, malnutrition, pollutants, infrastructure, energy and so on - demand rapid decision-taking," says Lobry. "Their development requires a massive mobilization of scientific knowledge to enable them to say: 'the following steps may be considered, their implementation will take so long, these will be the costs incurred, and so on."'

Researchers must play a key role in setting up committees of experts who are competent and trustworthy, argues Lobry. Only those actively involved in the informal network of international research can suggest individuals who are competent to deal with particular issues. "The most important thing is that they be outstanding in their own field, and therefore have access to the best sources of information."

Lobry says that any significant social issue in a developing country has economic and political implications which affect industrialized countries, and that these countries cannot therefore be left to set up expert committees alone.

"Imagine a country with vast stretches of desert, willing to hire this land out to developed countries as a dump site for their toxic waste," he says. "The safety conditions and a fair remuneration for the service must be discussed. Can the country providing the service be expected to put its blind trust in the experts of the country which is buying the service? Obviously not."

The situation would be completely different if this country had a team of efficient physicists, who could draw up an opinion based on the quality of the expertise provided. The South must therefore urgently acquire a research body capable of tapping into the global corpus of scientific knowledge, and it is the duty of the North to assist them in this.

This is even true of mathematics, says Lobry. "Mathematical skills are lost or blunted unless they are maintained by research. Mathematicians must work at their own subject if they are to intervene effectively in other disciplines."

\title{
Swedes call for emphasis on access to knowledge
}

[LONDON] Unesco is being prompted by Sweden's national commission for the UN agency to play a more proactive role in the World Conference on Science by putting its weight behind calls for full public access to scientific knowledge. The Swedish commission would also like to see social scientists play a greater role at the Budapest conference than is currently planned.

Public access to knowledge, women in science, and investment in Third World universities have emerged as the three priority areas for Sweden's delegation to next month's conference. Swedish delegates are expected to press Unesco to end its position of neutrality and "take a stand" by supporting the interests of the developing world.

Most of Unesco's member countries are in the developing world, says Anders Falk, general secretary of the national commission. "Unesco should support them," he adds. For example, he says, "they need access to knowledge. Without this, they will never be able to develop." Unesco, says Falk, should oppose what he calls the "increasing privatization of knowledge".

Sweden has been at the forefront of developed countries in demanding that investment in basic research and higher education should be considered integral to the process of development. The country has one of the largest overseas research budgets, concentrating its aid on research activities in east and southern Africa.

Sweden's strategy for the Budapest con- ference has been agreed after three preparatory meetings, the last of which took place last week at Uppsala. The conference has generated considerable controversy, says Falk. Many delegates attending the preparatory meetings have voiced criticisms of the conference programme and of draft versions of the two final documents - a declaration and an 'agenda for action' — that the conference will be asked to adopt. One Swedish scientist called the drafts "toothless".

Another senior scientist says he will not attend the Budapest meeting because he is not convinced that his time there would be usefully spent. "I am hesitating in saying this because I know that many people in developing countries have put a lot of effort in preparing for this conference, and rate Unesco highly. But there will be too many people [at the meeting], and too much talk."

Falk says that few will disagree with the aims and objectives of the draft declaration. "But we don't know who will be responsible for implementing the recommendations," he says. The agenda for action, according to Falk, should have clear lines of responsibility.

Falk is also concerned that the conference programme could become dominated by natural scientists, even though Unesco had been presented with a rare opportunity to put together a "forward-looking" programme by bringing together natural scientists with social scientists and academics from the liberal arts.

\section{Nobel laureates lined up for US delegation}

[WASHINGTON] A pair of Nobel laureates, President Bill Clinton's science adviser, the president of the National Academy of Sciences, two immediate past presidents of the American Association for the Advancement of Science (AAAS), and a student from Illinois Math and Science Academy, are among a planned 20-strong US delegation to the World Conference on Science.

The list has been put together by the National Academy of Sciences, the main US contact point with the International Council for Science (ICSU) which is organizing the meeting with Unesco.

Although the members of the delegation have yet to be formally approved by the State Department, academy officials expect little change to the final list. This will be headed by Bruce Alberts, the president of the academy, and include Nobel laureates $F$. Sherwood Rowland of the University of California, Irvine, and Leon Lederman, director emeritus of the Fermi National Accelerator Centre. Neal Lane, the president's science adviser and head of the Office of Science and Technology Policy, will be accompanied by two of his staff members.

The delegation will include Jane Lubchenco, AAAS president in 1997, and the AAAS immediate past president M. R. C. Greenwood. Also present will be Maxine Singer, president of the Carnegie Institute of Washington, and Keith Winstein, a student from Illinois. Full text: http://helix.nature.com/wcs/a36.html 